volume of breath sample at a constant temperature for ethanol concentration. By means of gears this result is transferred to a digital read out which gives the estimated equivalent venous blood level of ethanol. In contrast to the remainder of the United Kingdom, where a colour change (Alcotest Draeger) determines whether a breath sample contains more than the permitted limit corresponding to $80 \mathrm{mg}$. of ethanol per $100 \mathrm{ml}$. of blood, in Northern Ireland the Ethanographe is used to give a reading equivalent to the venous blood ethanol level.

With the Ethanographes currently used in this province there was an excellent correlation between actual and derived blood levels when these were below $80 \mathrm{mg} . / 100 \mathrm{ml}$. The high blood levels studied were above those for which these machines are normally used as a screening device by officers of the law. At this range (over $110 \mathrm{mg} . / 100 \mathrm{ml}$.) we found a higher estimated blood concentration than that in venous blood. In order to be sure of getting an alveolar gas sample for analysis during anaesthesia it was felt necessary to have the patient rebreathe for a period of two minutes. During this time there was a rapid fall in both arterial and venous blood and hence alveolar levels. A bag sample taken over a twominute period would therefore be drawn from a range of alveolar concentration at the beginning of which time the blood level would be much higher than at the actual time of venous blood sampling. Thus these discrepancies are most likely to arise from causes unassociated with the breathalysers.

The change in the gearing ratio in the Ethanographe from the original $58: 1$ to the currently used $67: 1$ obviously gives an increased accuracy, as shown in Fig. 4. On this basis the unmodified Ethanographe would be expected to give an unusually low estimation of venous ethanol concentration.

Our thanks are due to the medical and nursing staff of Musgrave Park Hospital for their co-operation in this study and to Dr. A. J. Howard, of the Forensic Laboratory, Ministry of Commerce, and Mr. J. Taggart, technician in the same department, for their co-operation. Our thanks are due also to Mr. P. J. Howard and other members of the staff of the department of anaesthetics. During the course of this study Dr. Isaac was in receipt of a Commonwealth Universities Research Fellowship.

REFERENCES

Borkenstein, R. F., and Smith, H. W. (1961). Medicine, Scienc and the Law,

British Medical Association (1954). Recognition of Intoxication. London, British Medical Association.

Drew, G. C., Colquhoun, W. P., and Long, H. A. (1959). Medical Research Council, Memorandum, No. 38, pp. 67, 68.

Dundee, J. W. (1970). Anesthesia and Analgesia Current Researches. In press. undee, J. W., Isaac, M., Pandit, S. K., and McDowell, S. A. (1970) British fournal of Anaesthesia, 42, 300.

Dundee, J. W., Isaac, M., and Taggart, J. (1970). Quarterly fournal of Studies on Alcohol. In press.

Gostomzyk, J. G., Dilger, B., and Dilger, K. (1969). Zeitschrift für klinische Chemie und klinische Biochemie, 7, 162

Gostomzyk, J. G., and Streffer, C. (1960). Blutalkohol, 6, 211

Hill, I. D.' (1965). British Medical fournal, 1, 383

Jetter, W. W. (1941). Quarterly fournal of Studies on Alcohol, 2, 512

Morgan, W. H. D. (1965). Fournal of the Forensic Science Society, 5, 15.

Noordzij, P. C. (1969). Measuring devices and methods for determining blood alcohol concentration. Institute for Road Safety Research, (S.W.O.V.) Voorburg, Netherlands.

Payne, J. P., Foster, D. V., Hill, D. W., and Wood, D. G. L. (1967). British Medical fournal, 3, 819 .

Payne, J. P., Hill, D. W., and King, N. W. (1966). British Medical Fournal,

1, 196. 118. London, British Medical Association.

\title{
Benign Intracranial Hypertension following Corticosteroid Withdrawal in Childhood
}

\author{
B. G. R. NEVILLE, ${ }^{*} \ddagger$ M.B., B.S., M.R.C.P. ; J. WILSON, $†$ M.B., PH.D., M.R.C.P.
}

\begin{abstract}
Cummary: In an 18-month period seven children $\checkmark$ who were treated for a variety of neurological and non-neurological diseases, and in whom the corticosteroid or corticotrophin dosage was reduced, developed a syndrome indistinguishable from "benign intracranial hypertension." The total duration and rate of reduction of corticosteroid dosage and perhaps an underlying susceptibility to cerebral oedema appear to be important factors in this syndrome. Usually patients can be treated without the need for special neuroradiological studies. Possibly mild forms of this condition are not uncommon, but its pathogenesis is still uncertain.
\end{abstract}

\section{Introduction}

The syndrome of benign intracranial hypertension comprises headache and papilloedema occurring usually without focal neurological signs except occasionally a sixth-nerve palsy. Ventricular size is normal or small except in long-standing

\footnotetext{
- House-physician

† Consultant Neurologist. Department of Neurology, the Hospital for Sick Children, Great Ormond
Street, London W.C.1. ¥ Present address: National Hospital for Nervous Diseases, Queen Square,
London W.C.1.
}

cases, when some dilatation may occur. Though the condition is considered to be benign, some patients develop severe visual loss.

Benign intracranial hypertension has been reported in association with many conditions: (1) otitis media, possibly with lateral and sagittal sinus thrombosis (Symonds, 1952; Greer, 1962); (2) hypocalcaemia (Sugar, 1953); (3) administration of tetracycline (Fields, 1961), nalidixic acid (Boréus and Sundström, 1967), and vitamin A (Gerber et al., 1954); (4) primary Addison's disease (Jefferson, 1956); (5) reduction of corticosteroid dosage (Dees and McKay, 1959; Greer, 1963a). (6) Greer (1963b), described the occurrence of this syndrome at between the second and fifth months of pregnancy, at menarche (Greer, 1964a), and in secondary amenorrhoea (Greer, 1964b), and discussed the hypothesis that falling levels of circulating corticosteroid and rising levels of oestrogen are important factors in its pathogenesis.

The association of corticosteroid administration and benign intracranial hypertension was first suggested by Freyberg et al. (1957), and further independent reports followed (Dees and McKay, 1959; Valentine, 1959). These are mainly of children, and except for some of the earliest reports (Valentine, 1959; Laurence et al., 1960) this has always followed reduction of the dose of corticosteroids (Greer 1963a).

The clinical presentation was similar to that seen in other 
Details of Cases

\begin{tabular}{|c|c|c|c|c|c|c|c|}
\hline Case No. & Age & $\begin{array}{l}\text { Primary } \\
\text { Disease }\end{array}$ & $\begin{array}{c}\text { Maintenance } \\
\text { Corticosteroid or } \\
\text { Corticotrophin } \\
\text { Dosage per Day } \\
\text { (Prednisone) }\end{array}$ & $\begin{array}{c}\text { Rate of } \\
\text { Withdrawal }\end{array}$ & Other Drugs & $\begin{array}{l}\text { Reason for } \\
\text { Withdrawal }\end{array}$ & $\underset{\text { Presentation }}{\text { Clinical }}$ \\
\hline $1 \ldots$ & $8 \frac{1}{2}$ months & $\begin{array}{l}\text { Hirschsprung's } \\
\text { disease }\end{array}$ & $\begin{array}{l}15 \text { mg. for } 2 \frac{1}{2} \\
\text { months }\end{array}$ & $\begin{array}{l}15 \text { to } 0 \mathrm{mg} \text {. in } \\
1 \text { week }\end{array}$ & Nystatin orally & $\begin{array}{c}\text { Inappropriate } \\
\text { treatment }\end{array}$ & $\begin{array}{c}\text { Irritability, neck } \\
\text { retraction, and } \\
\text { bulging } \\
\text { fontanelle. } \\
\text { Normal fundi }\end{array}$ \\
\hline $2 \ldots$ & $3 t$ years & Infantile spasms & $\begin{array}{l}\text { Corticotrophin } \\
40 \text { units } 2 \text { days } \\
\text { out of } 3 \text { for } \\
13 \text { months }\end{array}$ & $\begin{array}{l}20 \text { to } 7 \text { units in } \\
1 \text { day }\end{array}$ & $\begin{array}{l}\text { Phenytoin. } \\
\text { Diazepam }\end{array}$ & $\begin{array}{l}\text { Side-effects, and } \\
\text { no longer } \\
\text { beneficial }\end{array}$ & $\begin{array}{l}\text { Irritability, } \\
\text { vomiting, and } \\
\text { papilloedema }\end{array}$ \\
\hline $3 \ldots$ & 32 years & $\begin{array}{l}\text { Acute hemiplegia } \\
\text { in childhood }\end{array}$ & 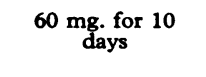 & 60 to 0 in 3 weeks & $\begin{array}{l}\text { Chlordiazepoxide. } \\
\text { Phenytoin }\end{array}$ & $\begin{array}{l}\text { No further } \\
\text { benefit } \\
\text { expected }\end{array}$ & $\begin{array}{l}\text { Vomiting and } \\
\text { papilloedema }\end{array}$ \\
\hline $4 \ldots$ & 51 years & $\begin{array}{l}\text { Nephrotic } \\
\text { syndrome }\end{array}$ & $\begin{array}{c}2.5 \text { to } 10 \mathrm{mg} \text {. for } \\
2 \text { years } 4 \\
\text { months }\end{array}$ & 7 to 2 in 3 weeks & Penicillin V & $\begin{array}{l}\text { Change of } \\
\text { therapy }\end{array}$ & $\begin{array}{c}\text { Headache, } \\
\text { vomiting, } \\
\text { drowsiness, and } \\
\text { papilloedema }\end{array}$ \\
\hline $5 \ldots$ & 7 years & $\begin{array}{l}\text { ? Encephalitis. } \\
\text { "Acute brain- } \\
\text { swelling" }\end{array}$ & $\begin{array}{l}80 \text { to } 100 \mathrm{mg} \text {. for } \\
14 \text { days }\end{array}$ & $\begin{array}{l}80 \text { to } 15 \text { in } 18 \\
\text { days. } 15 \text { to } 0 \text { in } \\
7 \text { days }\end{array}$ & $\begin{array}{l}\text { Diazepam. } \\
\text { Phenytoin. } \\
\text { Chlorpromazine }\end{array}$ & $\begin{array}{l}\text { No further } \\
\text { benefit } \\
\text { expected }\end{array}$ & $\begin{array}{c}\text { Irritability, } \\
\text { vomiting, and } \\
\text { papilloedema }\end{array}$ \\
\hline $6 \ldots$ & 12 years & $\begin{array}{l}\text { Nephrotic } \\
\text { syndrome }\end{array}$ & $\begin{array}{c}2.5 \text { to } 60 \mathrm{mg} \text {. for } \\
2 \text { years }\end{array}$ & $\begin{array}{c}60 \text { to } 22 \cdot 5 \text { in } \\
1 \text { day }\end{array}$ & Tetracycline & $\begin{array}{l}\text { Change of } \\
\text { therapy }\end{array}$ & $\begin{array}{l}\text { Headache, } \\
\text { vomiting, } \\
\text { diplopia, } \\
\text { blurring of } \\
\text { vision, and } \\
\text { papilloedema }\end{array}$ \\
\hline $7 \ldots$ & 13 years & $\begin{array}{l}\text { Ulcerative } \\
\text { colitis }\end{array}$ & $\begin{array}{l}4 \text { to } 10 \mathrm{mg} \text {. for } \\
2 \text { years. } 50 \text { to } \\
60 \text { mg. for } 4 \\
\text { weeks }\end{array}$ & 100 to 0 in 7 days & $\begin{array}{l}\text { Bethanidine. } \\
\text { Phenobarbitone. } \\
\text { Phenytoin. } \\
\text { Chlorothiazide. } \\
\text { Ampicillin }\end{array}$ & Side-effects & $\begin{array}{l}\text { Headache, } \\
\text { drowsiness, and } \\
\text { papilloedema }\end{array}$ \\
\hline
\end{tabular}

cases of benign intracranial hypertension with vomiting and headache, soon followed by gross papilloedema in an essentially well child. In Greer's (1963a) series of five patients three developed visual deterioration, four had lateral rectus palsies, and one, whose ventricular pressure exceeded $600 \mathrm{~mm}$. C.S.F., required an emergency subtemporal decompression to save vision. Many patients were submitted to potentially hazardous neuroradiological investigations, which is an additional reason why the condition may not necessarily be benign.

The increased use of corticosteroids and corticotrophin in paediatric practice appears to be producing an increasing incidence of intracranial hypertension. We wish to report seven cases collected in 18 months at the Hospital for Sick Children in order to emphasize the frequency of this condition, the problems of management that were posed, and to discuss its prevention.

The ages of these patients ranged from $8 \frac{1}{2}$ months to 13 years and all were male, though we have no other evidence that this is a sex-limited condition. The main clinical data are presented in the Table and brief descriptions of each patient are included below. All patients had a normal plasma calcium level.

\section{Case Reports}

Case 1 (H.S.C. No. 418624).--Symptoms of diarrhoea and constipation were treated with prednisone before Hirschprung's disease was diagnosed. The symptoms on steroid withdrawal raised the possibility of hydrocephalus or meningitis, but there were no focal signs, the E.E.G. was normal, skull $x$-ray films showed minimal suture separation, and lumbar puncture gave normal fluid at a pressure of $240 \mathrm{~mm}$. Prednisone $10 \mathrm{mg}$. daily produced rapid improvement and was withdrawn over two months.

Case 2 (H.S.C. No. 418017).-This boy was severely retarded from birth and had developed gross cushingoid features and hypertension on corticotrophin given for infantile spasms. The significance of his irritability and vomiting was only clear when three days after corticotrophin reduction moderate papilloedema developed. Prednisone $10 \mathrm{mg}$. twice daily produced rapid resolution of symptoms and was withdrawn over three months.
Case 3 (H.S.C. No. 409175).-This boy developed acutely a right hemiparesis with focal seizures and became aphasic and uncomprehending. A skull $x$-ray picture and a left carotid arteriogram were normal. The hemiparesis recovered completely during the time of prednisone administration. Vomiting occurred immediately after withdrawal at another hospital. Resolving papilloedema was discovered only six weeks later when he was readmitted, and was therefore not treated.

Case 4 (H.S.C. No. 389741).-This boy developed the nephrotic syndrome at 3 years. His disease responded poorly to corticosteroids, azathioprine, and cyclophosphamide. Reduction of prednisone from 7 to $2 \mathrm{mg}$. over three weeks was followed by lethargy and vomiting with papilloedema which responded dramatically to intravenous hydrocortisone, but the fundal changes took two months to resolve.

Case 5 (H.S.C. No. 410508).-This boy's illness consisted of the abrupt onset of extensor spasms with deepening coma closely resembling "acute brain swelling" or "toxic encephalopathy" (Eiben, 1967). He was treated with systemic corticosteroid and intravenous mannitol. He recovered consciousness in 10 days and steadily improved, with residual striatal rigidity. Five days after steroid withdrawal he began to vomit and gross papilloedema appeared. A carotid arteriogram and lumbar air encephalogram were normal. The clinical evidence of raised intracranial pressure rapidly resolved after reintroduction of prednisone.

Case 6 (H.S.C. No. 387311).-This 12-year-old boy with the nephrotic syndrome developed headache and vomiting three days after reduction of corticosteroid dosage; two days later diplopia with gross papilloedema appeared. The dosage of prednisone was maintained and symptoms subsided in one week, with resolution of papilloedema over 12 weeks.

Case 7 (H.S.C. No. 261765).-This 13-year-old boy suffered from ulcerative colitis from the age of 2 years. Five days after a severe relapse had been treated with $60 \mathrm{mg}$. of prednisone daily he developed brief major seizures with a left temporal E.E.G. abnormality. Neurological examination and spinal fluid were normal. Hydrocortisone $400 \mathrm{mg}$./day was given at the time of colectomy, and major seizures recurred. The diastolic blood pressure rose to $130 \mathrm{~mm} . \mathrm{Hg}$ and corticosteroids were therefore reduced. $\mathrm{He}$ soon complained of headaches, and after five days papilloedema developed; this disappeared over the next month following reintroduction of prednisone $10 \mathrm{mg}$. daily. 


\section{Discussion}

\section{Presentation}

The clinical features of these seven patients were very similar to those previously described. Irritability, headache, vomiting, and the development of papilloedema which was of ten gross with retinal haemorrhages, were observed in children in whom little neurological deterioration had occurred. One patient (Case 5) continued to improve neurologically with the return of speech during this time. Some children were, however, severely ill because of their primary condition. One (Case 1), who had open sutures, did not develop papilloedema-further supporting the view that the disc changes are the result of raised intracranial pressure and not an optic neuritis. Several patients were drowsy and unwell to a greater extent than is usually expected in benign intracranial hypertension. Vomiting was pronounced in three, one requiring intravenous fluids.

The condition may develop with corticosteroids or corticotrophin and the dose may be sufficient to prevent an Addisonian crisis. Frank adrenal insufficiency probably accounts for very few cases. This syndrome is apparently more common in children; the length of time on maintenance corticosteroids and the rate of withdrawal are important factors. Marked suppression of intrinsic corticosteroid output would not have been expected in Cases 3 and 5, who received corticosteroids for about five weeks. Both, however, had conditions in which some degree of cerebral oedema might have occurred independently. Steroid withdrawal in Case 4 was not rapid, but possibly generalized fluid retention was a factor. Tetracycline may have been an important factor in Case 6 . Many children have been treated for infantile spasms with corticotrophin 20 units twice daily for two weeks in the neurological unit of this hospital, and evidence of intracranial hypertension has never been seen afterwards.

The symptoms of irritability or headache developed within one week of reduction of the dose, and papilloedema took a few days to develop. The retinal changes were often gross, but transient visual deterioration occurred in only one patient (Case 6).

\section{Radiological Studies}

All patients except one were managed without special neuroradiological studies, and follow-up of these patients supports the clinical conclusion that they were not suffering from a space-occupying lesion or hydrocephalus. Such studies are not without risk, and difficulties may arise in locating the ventricles during ventriculography because of their small size. Case 7 undoubtedly had intracranial hypertension following reduction of corticosteroid dosage, but the coincidental major seizures, focal E.E.G. abnormality, and systemic illness raised doubts of a space-uccupying lesion. It was considered that the risk of special neuroradiological studies outweighed the advantages, a decision which was upheld by later events. The primary diagnosis of "acute brain swelling" in Case 5, however, was thought to be too uncertain for management without such studies.

\section{Treatment}

All patients except one were treated by raising the corticosteroid dosage followed by very gradual reduction. Greer (1963a) was diffident about the use of steroids in this situation, even though three of his five patients developed visual deterioration. We would suggest that the very low incidence of this complication in our series may be attributable to the reintroduction of corticosteroids. The dramatic remission of the unpleasant acute symptoms and the knowledge that the condition has been produced because of rapid steroid withdrawal are strong arguments in favour of the use of corticosteroids. We suspect that this may prevent visual deterio- ration and that the patient with acutely deteriorating vision might be saved operative decompression if high systemic dosages of corticosteroids were tried first.

From the point of view of prevention and management, therefore, the following suggestions are made.

(1) After prolonged corticosteroid administration, withdrawal should be gradual over at least one month and sudden reduction of the dosage by $50 \%$ or more should be avoided.

(2) If the illness being treated is associated with cerebral oedema-for example, status epilepticus, encephalitis, acute hemiplegia in childhood, lead poisoning, and cerebral anoxiasteroid withdrawal should be particularly cautious over two to three months.

(3) The possible significance of irritability and headache in a patient having steroids recently is obviously important, and to assist the correlation between the clinical state and steroid administration it is desirable that hospital notes should contain a single clearly identifiable card or sheet on which all steroid doses are charted.

(4) Though the clinical features are not specific, it is usually possible to manage the situation without special neuroradiological procedures. When there are focal neurological signs, a pronounced deterioration in consciousness, skull $x$-ray films showing evidence of long-standing raised intracranial pressure, or a deteriorating E.E.G., special procedures are fully justified.

(5) Reintroduction of two-thirds to one-half of the original dose of corticosteroids and gradual reduction over a period of two to three months has been found to be effective. If vision is deteriorating more urgent measures, such as dexamethasone or intravenous hydrocortisone (up to $400 \mathrm{mg}$./day), may be necessary, but operative decompression should not be deferred if vision continues to deteriorate.

\section{Pathogenesis}

The pathogenesis of this condition remains uncertain. The frequent finding of a distended subarachnoid space might suggest failure of normal absorption of cerebrospinal fluid. On the other hand, corticosteroids are known to have a "brain-shrinking" effect in cerebral oedema, and it is tempting to assume that cerebral oedema results from too rapid withdrawal.

In this connexion the possibility of an alteration of calcium metabolism is worth consideration. It is well recognized that hypocalcaemia may be associated with intracranial hypertension, and, though serum calcium levels in this condition and in Cushing's syndrome are usually normal, there is evidence that calcium metabolism may be disturbed in conditions of suprarenal insufficiency (Taylor and Caven, 1927; Leemska et al., 1957; Geschwind, 1961).

We wish to thank the members of the medical and surgical staff of the Hospital for Sick Children, Great Ormond Street, for permission to include patients under their care in this study.

\section{REFERENCES}

Boréus, L. D., and Sundstrő̀m, B. (1967). British Medical fournal, 2, 744.

Dees, S. C., and McKay, H. W. (1959). Pediatrics, 23, 1143.

Eiben, R. M. (1967). Pediatric Clinics of North America, 14, 797

Fields, J. P. (1961). Fournal of Pediatrics, 58, 74.

Freyberg, R. H., Bernsten, C. A., and Hellman, L. (1957). Arthritis and Rheumatism, 1, 215 .

Gerber, A., Raab, A. P., and Sobel, A. E. (1954). American fournal of Medicine, 16, 729 .

Geschwind, I. I. (1961). In Mineral Metabolism, ed. C. L. Comar, and F. Bronner, vol 1, Part B, p. 407. New York, Academic Press.

Greer, M. (1962). Neurology (Minneapolis), 12, 472.

Greer, M. (1963a). Neurology (Minneapolis), 13, 439.

Greer, M. (1963b). Neurology (Minneapolis), 13, 670.

Greer, M. (1964a). Neurology (Minneapolis), 14, 569.

Greer, M. (1964b). Neurology (Minneapolis), 14, 668.

Jefferson, A. (1956). Fournal of Neurology, Neurosurgery and Psychiatry, 19,

Laurence, B. M., Matthews, W. B., and Shephard, R. H. (1960). Lancet, 1, 701.

Leemska, C. H. W., De Graeff, J., and De Cock, J. (1957). Acta Medica Scandinavica, 156, 455 .

Sugar, O. (1953). Archives of Neurology and Psychiatry, 70, 86.

Symonds, C. (1952). Annals of the Royal College of Surgeons of England, 10, 347.

Taylor, N. B., and Caven, W. R. (1927). American Fournal of Physiology, 81,

511.
Valentine, G. H. (1959). Lancet, 1, 892. 